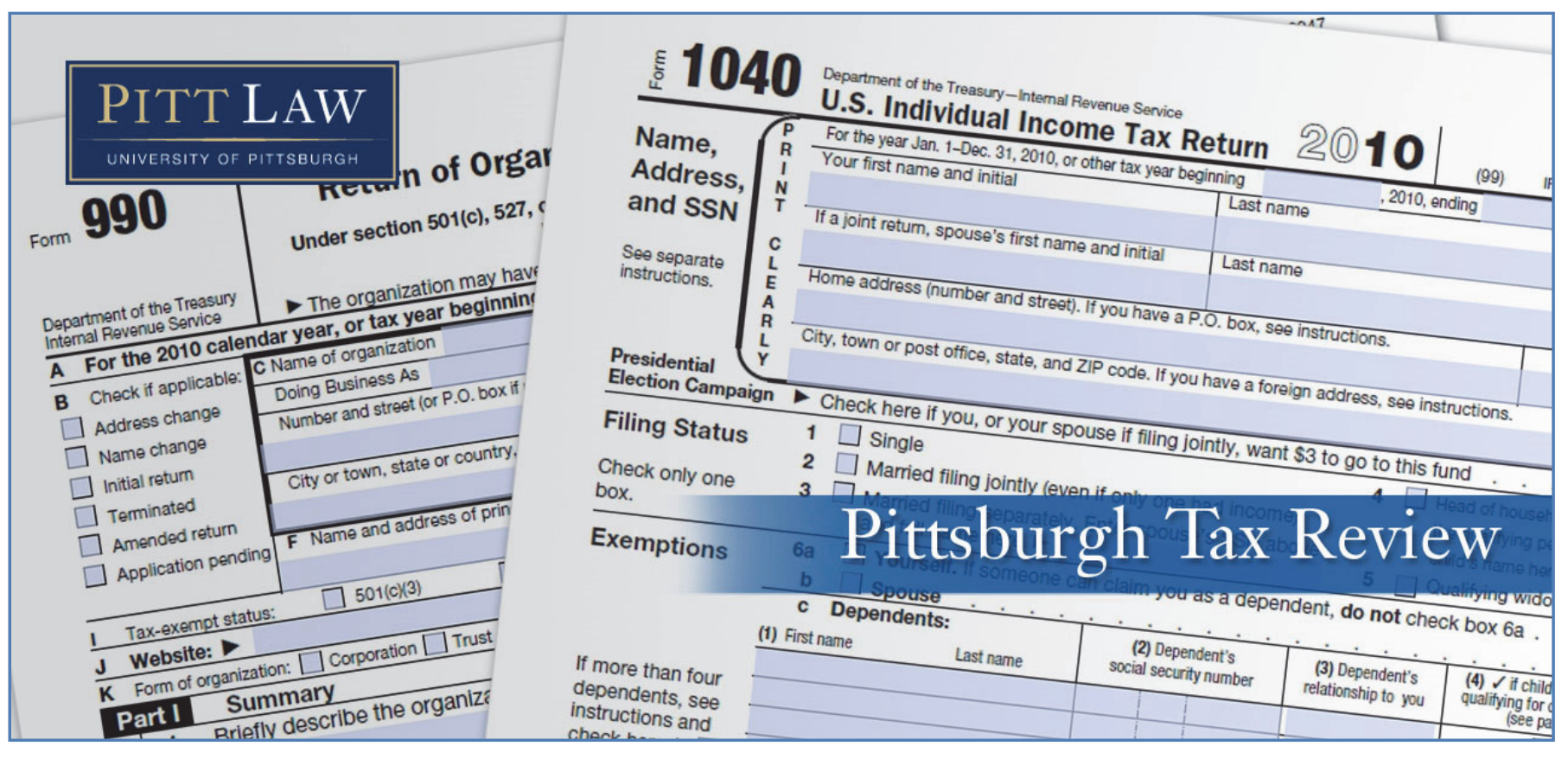

Volume 16 (2019) | ISSN 1932-1821 (print) 1932-1996 (online)

DOI 10.5195/taxreview.2019.98 | http://taxreview.law.pitt.edu

\title{
CALLED TO SERVE: ELEVATING HUMAN-PERFORMED CAREGIVER AND VOLUNTEER WORK IN AN ERA OF AI-ROBOTIC TECHNOLOGIES
}

Hilary G. Escajeda

\section{(c) EY-NC-ND}

This work is licensed under a Creative Commons Attribution-Noncommercial-No Derivative Works 3.0 United States License.

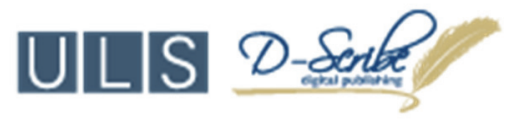

This journal is published by the University Library System of the University of Pittsburgh as part of its D-Scribe Digital Publishing Program, and is cosponsored by the University of Pittsburgh Press. 


\title{
CALLED TO SERVE: ELEVATING HUMAN-PERFORMED CAREGIVER AND VOLUNTEER WORK IN AN ERA OF AI-ROBOTIC TECHNOLOGIES
}

\author{
Hilary G. Escajeda*
}

The Internal Revenue Code distinguishes between market and nonmarket activities and articulates a framework for taxing and classification. ${ }^{1}$ For example, $\S 61$ of the Code captures market activities in its broad definition of "gross income" as "all income from whatever source derived." 2 Nonmarket activities, generally outside the reach of the Code, include "friendship, affection, altruistic behavior, a sense of commitment or belongingness, and family ties." "As such, personal, living, and family expenses are generally not deductible under $\S 262 .{ }^{4}$

Tax issues arise when distinguishing "market" from "nonmarket" activities. The social and economic value provided by volunteers and unpaid caregivers represents one such knotty entanglement. These (predominantly female) community members dedicate their time and talents to assisting the young, elderly, homeless, and disabled. ${ }^{5}$ While this altruistic decision to serve the community yields positive social rewards, such rewards are

\footnotetext{
* JD, University of Denver Sturm College of Law, 1997; LLM, University of Denver Sturm College of Law, 2010. Ms. Escajeda has practiced tax law in Colorado for twenty years and serves as an adjunct professor for the University of Denver, Graduate Tax Program. This Essay is dedicated to Reverend Tina Yankee (author's Mother) who heard and responded to a call to serve the poor and forgotten in her ministry work for Our Savior's Lutheran Church (Denver, CO) and Colorado Council of Churches.

${ }^{1}$ Tsilly Dagan, Itemizing Personhood, 29 VA. TAX REV. 93, 95 (2009); see, e.g., Nancy C. Staudt, Taxing Housework, 84 GEO. L.J. 1571, 1576 (1996).

${ }^{2}$ I.R.C. $\S 61(a)$.

${ }^{3}$ Dagan, supra note 1, at 95. Tax law also classifies economic activities into "nondeductible, personal consumption or deductible income-producing expenses." Id.

${ }^{4}$ I.R.C. $\S 262$ (a); Treas. Reg. § 1.262-1(a) (as amended in 2014).

${ }^{5}$ Hannah Roman, Foster Parenting as Work, 27 YALE J.L. \& Feminism 179, 202 (2016) (“Child care, elder care, and care of the disabled, like foster care, are fields in which women, and particularly women of color, are overrepresented.").
}

Pitt Tax Review | ISSN 1932-1821 (print) 1932-1996 (online)

DOI 10.5195/taxreview.2019.98 | http://taxreview.law.pitt.edu 
counterbalanced by adverse economic consequences for the unpaid caregivers who lose lifetime earnings. ${ }^{6}$ This clash between societal nonmarket expectations and individual market realities further reinforces traditional gender roles and the hackneyed dichotomy of the sainted mother or greedy $\mathrm{b}^{*}$ tch. $^{7}$

Although the status quo of the traditional female caregiver has managed to muddle forward, it may begin to unwind as increasingly capable technologies dislodge humans from full-time employment and compel a redefinition of valuable work. ${ }^{8}$ Given this backdrop, this Essay seeks to open a dialogue for developing thoughtful, modern tax policies. Part I outlines the vocational endeavors of historically female community members who serve as caregivers and social volunteers. Next, Part II summarizes the economic value of volunteer and caregiver services. Part III examines whether tax policies should adopt a more expansive definition of beneficial occupations, as artificial intelligence (AI) and robotic technologies reconfigure the marketplace. Then, Part IV recommends that policymakers amend the Code to include a refundable tax credit for caregiver and volunteer work. Essentially, this Essay encourages a "multi-faceted" understanding of economic and social roles "so that our human traits (such as courage or care)

${ }^{6}$ Staudt, supra note 1, at 1647 (arguing that “to improve women's economic security, housework must be recognized as valuable and productive").

${ }^{7}$ See Dagan, supra note 1, at 111,115-16, 120 (discussing imputed income and home/family care); see also Roman, supra note 5, at 205-06 ("The stigmatization of paid mothering makes foster parents, like other caregivers, vulnerable to financial exploitation.").

"B*tch" spelling used in deference to Rev. Yankee (author's Mother). See Yvonne A. Tamayo, Rhymes with Rich: Power, Law, and the Bitch, 21 ST. ThOMAS L. Rev. 281, 287 (2009) (examining how women who do not accept socially assigned roles of submission are labeled and condemned as bitches). Tamayo writes:

For over six centuries, bitch has been used as a term of contempt toward women. Originally, bitch referenced a sensual or promiscuous woman, and later evolved to include a woman considered angry, spiteful, or malicious. Today, the term includes a woman deemed aggressive, competitive, or domineering. Despite its definitional nuances, bitch remains an unequivocal expression of hostility used to denounce, harass, and insult women who, by acting outside of their prescribed gender roles, threaten the established paradigm of power as an inherently male characteristic.

Id. at 281-82 (footnotes omitted).

${ }^{8}$ See Geoff Mulgan, Measuring Social Value, Stan. Soc. InNOvation ReV., Summer 2010, at 38-39; Michael E. Porter \& Mark R. Kramer, Creating Shared Value: How to Reinvent Capitalism—and Unleash a Wave of Innovation and Growth, HARV. BUS. REV., Jan.-Feb. 2011, at 15.

Pitt Tax Review | ISSN 1932-1821 (print) 1932-1996 (online)

DOI 10.5195/taxreview.2019.98 | http://taxreview.law.pitt.edu 
or callings (such as business leader or stay-at-home parent) are not prescribed by gender or sex." Finally, Part V offers conclusions regarding the consequences of implementing a refundable tax credit for caregiver and volunteer work.

\section{A CALL TO SERVE OTHERS}

Beyond income, work provides people with meaning, purpose, and selfrespect. ${ }^{10}$ According to a 2018 report by the Council on Foreign Relations, meaningful work supports thriving and healthy communities, and it contributes to individual and social well-being. ${ }^{11}$ In her research, Yale University Professor Amy Wrzesniewski distinguishes between work for wages and work that provides meaning. ${ }^{12}$ She describes how community members generally see their work as fitting within one of three categories: a job, a career, or a calling. ${ }^{13}$ She explains that people view work as a "job" when such efforts represent a financial necessity and not necessarily a satisfying life experience. ${ }^{14}$ Individuals with "careers" regard their work as an opportunity to win or "advance[]." A "call," in contrast, provides individuals with a source of "enjoyment" because they are doing "socially useful work." 16

The word "calling" originates from religious texts and represents the shared virtues of charity, community service, and civic responsibility. ${ }^{17}$

${ }^{9}$ ELCA TASK ForCe ON WOMEN \& JUSTICE, ONE In EVANGELICAL LUTHERAN CHURCh IN AM., DRAFT SOCIAL STATEMENT ON WOMEN AND JUSTICE 8, 45-46 (2017).

${ }^{10}$ John Engler et al., Council on Foreign Relations, The Work Ahead: Machines, SKILLS, AND U.S. LEADERSHIP IN THE TWENTY-FIRST CENTURY 10 (2018).

${ }^{11} I d$.

${ }^{12}$ Amy Wrzesniewski et al., Jobs, Careers, and Callings: People's Relations to Their Work, $31 \mathrm{~J}$. RESEARCH IN PERSONALITY 21, 22 (1997).

${ }^{13} I d$. at 21 .

${ }^{14} \mathrm{Id}$.

${ }^{15} \mathrm{Id}$.

${ }^{16} I d$.

${ }^{17}$ Id.; see, e.g., Neil Hamilton et al., Professional Formation/Professionalism's Foundation: Engaging Each Student's and Lawyer's Tradition on the Question "What Are My Responsibilities to Others?,” 12 U. ST. THOMAS L.J. 271, 273 (2016) (describing how acts of charity, responsibility to others,

Pitt Tax Review | ISSN 1932-1821 (print) 1932-1996 (online) DOI 10.5195/taxreview.2019.98 | http://taxreview.law.pitt.edu 
While the modern view of a calling no longer tightly links to scripture, it still encompasses socially valued work that people feel called to do, and provides the doer with value and dignity. ${ }^{18}$ As technology continues to disrupt the workplace, a call to serve offers humans a myriad of opportunities to perform meaningful work. As discussed in Part II, meaningful work also generates significant economic value.

\section{CAREGIVERS AND VOLUNTEERS}

Billions of caregivers answer calls to serve by assisting families, friends, and communities. ${ }^{19}$ Although important to society, these nurturing activities tend to reinforce traditional gender roles. For example, a 2015 McKinsey Global Institute Report found that women perform seventy-five percent of unpaid caregiver work. ${ }^{20}$ The report estimated "that unpaid work being undertaken by women today amounts to as much as $\$ 10$ trillion of output per year, roughly equivalent to 13 percent of global GDP." 21 In the United States,

and being of service to the community represent core teachings in Christianity, Judaism, Islam, Buddhism, and Hinduism and in secular philosophies).

${ }^{18}$ Wrzesniewski, supra note 12, at 22; see Monique Valcour, The Power of Dignity in the Workplace, HARV. BuS. REV. (Apr. 28, 2014), https://hbr.org/2014/04/the-power-of-dignity-in-theworkplace ("[D]ignity is fundamental to well-being and to human and organizational thriving."); see also POPE FRANCIS, ENCYCLICAL LETTER LAUDATO SI': ON CARE FOR OUR COMMON HOME 127 (May 24, 2015), http://w2.vatican.va/content/dam/francesco/pdf/encyclicals/documents/papa-francesco

20150524_enciclica-laudato-si_en.pdf ("Work should be the setting for this rich personal growth, where many aspects of life enter into play: creativity, planning for the future, developing our talents, living out our values, relating to others, giving glory to God."). Pope Francis also warned of technological progress that replaces the need for human-performed work would be "detrimental to humanity." Id. ๆ 128.

${ }^{19}$ See Katharine Silbaugh, Commodification and Women's Household Labor, 9 YALE J.L. \& Feminism 81, 110-19 (1997); Katharine Silbaugh, Turning Labor into Love: Housework and the Law, 91 Nw. U. L. REV. 1, 25-27 (1996).

20 Jonathan Woetzel et al., McKinsey Glob. Inst., The Power of Parity: How AdVANCING WOMEN's EQUality CAN AdD \$12 TRILlion to Global Growth 2 (2015), https://www.mckinsey.com/ /media/McKinsey/Featured\%20Insights/Employment\%20and\%20Growth/ How $\% 20$ advancing\%20womens\%20equality $\% 20$ can\%20add\%2012\%20trillion\%20to\%20global\%20gr owth/MGI\%20Power\%20of\%20parity_Full\%20report_September\%202015.ashx.

${ }^{21} I d$.

Pitt Tax Review | ISSN 1932-1821 (print) 1932-1996 (online)

DOI 10.5195/taxreview.2019.98 | http://taxreview.law.pitt.edu 
unpaid care work performed by women is valued at approximately $\$ 1.5$ trillion per year. ${ }^{22}$

Caregivers also strengthen our local economies and communities through service to our schools, government, and other charitable organizations. ${ }^{23}$ Despite the donation of their time and efforts, the financial needs of caregivers are often overlooked. For example, a 2011 AARP study found that unpaid caregivers over the age of fifty who provide care to a friend or family member as their calling lose an average of " $\$ 303,880$ on average, in lost income and benefits over a caregiver's lifetime." ${ }^{24}$ Because caregiving has deep roots in traditional gender roles, efforts to value this socially and economically essential work will likely encounter resistance. ${ }^{25}$

In view of these financial inequities, modern public policies should explicitly recognize that caregiving work warrants compensation. Policymakers should, therefore, design tax policies that respect the value of nurturing activities and services, such as care for children, elders, the disabled, and others in need. Before tackling this topic, Part III explores how technology will restructure the workplace, thereby compelling a radical rethink of what constitutes "valuable" work beyond the current social conception that esteems large salaries and prestigious career titles.

${ }^{22}$ Id. at 30; see Lynn Feinberg ET AL., AARP Pub. Policy InSt., VAluing the InVAluable: 2011 Update: The Growing Contributions AND Costs OF FAMILY CAREgiving 1 (2011), http:// assets.aarp.org/rgcenter/ppi/ltc/i51-caregiving.pdf.

${ }^{23}$ See generally Tara Kpere-Daibo, Note, Employment Law-Antidiscrimination-Unpaid and Unprotected: Protecting Our Nation's Volunteers Through Title VII, 32 U. ARK. LITTLE ROCK L. REV. 135, 135-37 (2009) (providing U.S. volunteer estimates for 2007, describing presidential support for volunteerism, and noting that the sixty million volunteer estimate does not include "unpaid work [in other words, internships] in public and for-profit industries").

${ }^{24}$ Feinberg ET AL., supra note 22, at 6, 18 n.39 (citing MetLife MAture MKt. InST., The MetLife Study of Caregiving Costs to Working Caregivers: Double Jeopardy for Baby BOOMERS CARING FOR THEIR PARENTS 15 (2011)); see Staudt, supra note 1, at 1598, 1618.

${ }^{25}$ Although outside the scope of this Essay, a fundamental question is why gender functions as a barrier for those called to serve their families and communities?

Pitt Tax Review | ISSN 1932-1821 (print) 1932-1996 (online) DOI 10.5195/taxreview.2019.98 | http://taxreview.law.pitt.edu 


\section{WORK IN AN ERA OF TECHNOLOGICAL DISINTERMEDIATION}

As technology disintermediates (i.e., removes) humans from paid work and market transactions, ${ }^{26}$ tax policies should foster meaningful work opportunities. The McKinsey Global Institute recently issued a report warning that $\mathrm{AI},{ }^{27}$ intelligence amplification or augmentation, ${ }^{28}$ and robotic advances $^{29}$ have the potential to automate more than two thousand work activities across eight hundred occupations, which may affect fifty percent of paid activities people perform in the global economy. ${ }^{30}$ In sixty percent of the studied occupations, at least thirty percent of job activities may eventually be automated. ${ }^{31}$ Highly educated professionals are not immune from this threat. $^{32}$

The extent to which AI will disintermediate humans from the workforce generates substantial debate. ${ }^{33}$ While optimists generally assert that, over the

\footnotetext{
${ }^{26}$ Disintermediation, TECHOPEDIA, https://www.techopedia.com/definition/1470/ disintermediation (last visited Mar. 25, 2019).

${ }^{27}$ Artificial intelligence (AI) is "an area of computer science that emphasizes the creation of
} intelligent machines that work and react like humans" in areas including "speech recognition, learning, planning, [and] problem solving." Artificial Intelligence (AI), TECHOPEDIA, https://www .techopedia.com/definition/190/artificial-intelligence-ai (last visited Mar. 25, 2019).

${ }^{28}$ Intelligence augmentation is the process by which technology enhances a human being's own intelligence or decision-making skills rather than creating an "independent artificial intelligence." Intelligence Amplification (IA), TECHOPEDIA, https://www.techopedia.com/definition/32577/ intelligence-amplification-ia (last visited Mar. 25, 2019).

${ }^{29}$ Robotics refers to "the engineering, construction, and operation of robots" to perform tasks or play a role in various commercial and consumer uses. Robotics, TECHOPEDIA, https://www.techopedia .com/definition/32836/robotics (last visited Mar. 25, 2019).

30 James Manyika et al., McKinsey Glob. Inst., A Future That Works: Automation, EMPloyment, AND PRODUCTIVITY 4-5 (Jan. 2018), https://www.mckinsey.com/ /media/McKinsey/ Featured\%20Insights/Digital\%20Disruption/Harnessing\%20automation\%20for\%20a\%20future $\% 20$ that $\% 20$ works/MGI-A-future-that-works_Full-report.ashx ("We estimate that 50 percent of the activities that people are paid to do in the global economy have the potential to be automated by adapting currently demonstrated technology."). The report also notes prior significant workplace shifts in the United States. Specifically, "the share of farm employment fell from 40 percent in 1900 to 2 percent in 2000, while the share of manufacturing employment fell from approximately 25 percent in 1950 to less than 10 percent in 2010." Id. at 12 .

${ }^{31}$ Id. at 5; see Getting Ready for the Future of Work, MCKINSEY Q., Sept. 2017, at 62.

${ }^{32}$ Getting Ready for the Future of Work, supra note 31, at 63-64; see PETER STONE ET AL., Stanford Univ., ARTificial InTElligence and Life in 2030: ONE Hundred Year Study on ARTIFICIAL INTELLIGENCE 38 (2016), https://ai100.stanford.edu/sites/default/files/

Pitt Tax Review | ISSN 1932-1821 (print) 1932-1996 (online)

DOI 10.5195/taxreview.2019.98 | http://taxreview.law.pitt.edu 
long term, enough new jobs will be created to solve technological unemployment, the near and midterm outlook is uncertain. ${ }^{34}$ As such, modern tax policies should be developed to account for increasing demands for "nonmarket" services that nourish healthy communities such as altruism, volunteerism, friendship, and family ties. ${ }^{35}$

Developing forward-looking tax policies to address technological unemployment will require that policymakers redefine what constitutes socially and economically "valuable" transactions - in other words, work. For government leaders whose constituents have been negatively impacted by technology - that is, they are unemployed, underemployed, or unable to support their families - a threshold question is whether tax policies should prefer technology-performed or human-performed work? Additionally, policymakers should consider:

1. If AIs and robots perform human jobs, how will displaced unemployed humans earn an income and pay taxes?

2. If AIs and robots displace the human workforce, how will governments obtain the necessary tax revenues to fund operations?

3. Does the distinction between market and nonmarket activities remain appropriate in an era where technology increasingly performs market activities?

Meanwhile, some leaders in the technology industry are grappling with these complex social and economic questions. Perhaps recognizing the

ai100report10032016fnl_singles.pdf ("AI is also creeping into [the] high end of the spectrum, including professional services not historically performed by machines."). See generally MARTIN FORD, THE RISE OF THE RoBOTS: TECHNOLOGY AND THE THREAT OF A JOBLESS FuTURE 96-104 (2015) (describing the development of IBM Watson technology and the threat to "human knowledge workers").

${ }^{33}$ See, e.g., Erik Brynjolfsson \& Andrew McAfee, The Second Machine Age: Work, Progress, AND Prosperity IN A Time OF BRILliant TeChNOLOGIES 173-81 (2014); see Orly Mazur, Taxing the Robots, 46 PEPP. L. REV. 277, 283-85 (2019); Matthew Dimick, Better Than Basic Income? Liberty, Equality, and the Regulation of Working Time, 50 IND. L. REV. 473, 497-98 (2017).

${ }^{34}$ BRYNJOLFSSON \& MCAFEE, supra note 33, at 175-80 (describing various perspectives about technological unemployment and then concluding that there will be ongoing economic disruption for the foreseeable future).

${ }^{35}$ Dagan, supra note 1 , at 95.

Pitt Tax Review | ISSN 1932-1821 (print) 1932-1996 (online) DOI 10.5195/taxreview.2019.98 | http://taxreview.law.pitt.edu 
Frankenstein-esque ${ }^{36}$ nature of their creations, or merely out of economic self-preservation, industry leaders are discussing strategies for smoothing the transition to an AI-robot dominated work and marketplace. ${ }^{37}$ For example, in 2017, Bill Gates suggested imposing a "robot tax" to fund displaced worker retraining programs and volunteer and caregiver jobs. ${ }^{38}$ Mark Zuckerberg and other Silicon Valley leaders have encouraged policymakers to consider universal basic income for engineering economic, social, and political stability. ${ }^{39}$

Since these big-picture questions require careful study and debate beyond the scope of this Essay, the remainder of this Essay focuses on the narrow challenge of the tax treatment of caregiver and volunteer work. Specifically, this Essay argues that, because caregiver and volunteer work enriches our families and communities, forward-looking policymakers

\footnotetext{
36 See generally MARY WOLlSTONECRAFt SHELley, FrankenSTEIN OR, THE MODERN PROMETHEUS (1818).

${ }^{37}$ KAI-Fu LeE, AI Superpowers: China, Silicon VAlley, AND the NeW World ORder 20809 (2018) (AI expert and former President of Google China, Kai-Fu Lee writes the following about Silicon Valley entrepreneurs, "I worry that there's also a more self-interested component: Silicon Valley entrepreneurs know that their billions in riches and their role in instigating these disruptions make them an obvious target of mob anger if things ever spin out of control."). Lee then calls Silicon Valley's "magic wand" belief in universal basic income as tantamount to delivering opiates to the masses. Id. at 208-10. He pointedly observes, "And that numbing effect goes both ways: not only does it ease the pain for those displaced by technology; it also assuages the conscience of those who do the displacing." Id. at 210.
}

${ }^{38}$ Kevin J. Delaney, The Robot That Takes Your Job Should Pay Taxes, Says Bill Gates, QUARTZ (Feb. 17, 2017), https://qz.com/911968/bill-gates-the-robot-that-takes-your-job-should-pay-taxes/ ("Gates said that a robot tax could finance jobs taking care of elderly people or working with kids in schools, for which needs are unmet and to which humans are particularly well suited."); Emily Price, Bill Gates' Plan to Tax Robots Could Become a Reality in San Francisco, ForTune (Sept. 5, 2017), http://fortune.com/2017/09/05/san-francisco-robot-tax/.

${ }^{39}$ Chris Weller, Mark Zuckerberg Doubles Down on Universal Basic Income After a Trip to Alaska, BUS. INSIDER (July 5, 2017, 10:23 AM), https://www.businessinsider.com/mark-zuckerberg-universalbasic-income-alaska-2017-7 (identifying other Silicon Valley supporters of universal basic income: Tesla CEO Elon Musk, Y Combinator President Sam Altman, and eBay founder Pierre Omidar); see Annie Lowrey, The Anti-Poverty Experiment That Could Fix America's Broken Welfare System, N.Y. MAG.: INTELLIGENCER (May 1, 2016), http://nymag.com/daily/intelligencer/2016/04/first-universal-basicincome-experiment.html ("Silicon Valley is in the midst of a love affair with [universal basic income], arguing that when robots come to take all of our jobs, we're going to need stronger redistributive policies to help keep families afloat."); see also LEE, supra note 37, at 222 (questioning the "laissez-faire individualism" of universal basic income and instead recommending that any government payments be conditioned on the recipient performing some socially beneficial community work); Mazur, supra note 33 , at 325-27 (concluding that universal basic income does not represent a viable political solution in the United States).

Pitt Tax Review | ISSN 1932-1821 (print) 1932-1996 (online)

DOI 10.5195/taxreview.2019.98 | http://taxreview.law.pitt.edu 
should (1) expressly define "valuable" work to include caregiving services, and (2) introduce tax legislation that links individual economic benefit with the performance of caregiver work.

\section{REFUNDABLE TAX CREDIT FOR CAREGIVER AND VOLUNTEER WORK}

Under current tax law, individuals and corporations may make $\S 170$ deductible contributions to qualified charitable organizations. ${ }^{40}$ However, under Treasury Regulation section 1.170A-1 $(\mathrm{g})$, no deduction is allowed for contribution of services. ${ }^{41}$ This "no contribution of services" rule prevents more than 61.8 million volunteers who perform 8 billion hours of service, worth an estimated $\$ 162$ billion, from factoring their charitable services into their tax liabilities. ${ }^{42}$

A potential legislative solution emerging from two decades of tax theory posits that $\S 170$ should recognize the contribution of donated services in the form of tax credits. ${ }^{43}$ In particular, this Essay recommends that policymakers

${ }^{40}$ See generally Treas. Reg. $§ 1.170 \mathrm{~A}-1$ (as amended in 2018) (specifying the form, timing, value, and other limits for tax-deductible charitable contributions).

${ }^{41}$ Treas. Reg. $\S 1.170 \mathrm{~A}-1(\mathrm{~g})$ provides that "unreimbursed expenditures made incident to the rendition of services to an organization contributions to which are deductible may constitute a deductible contribution."

${ }^{42}$ Grace Soyon Lee, Mitigating the Effects of an Economic Downturn on Charitable Contributions: Facing the Problem and Contemplating Solutions, 22 CORNELL J.L. \& PUB. POL'Y 589, 627 (2013) (citing 2008 volunteer hours and economic value estimates).

${ }^{43}$ See, e.g., Nancy C. Staudt, The Hidden Costs of the Progressivity Debate, 50 VAND. L. REV. 929 , 988 (1997) (proposing an alternative "charitable service credit" for individuals who donate their time and talents to charitable organizations); see Alice M. Thomas, Re-envisioning the Charitable Deduction to Legislate Compassion and Civility: Reclaiming our Collective and Individual Humanity Through Sustained Volunteerism, 19 KAN. J.L. \& PUB. POL'Y 269, 278, 332, 336 (2010) (Professor Thomas advocates tax incentives to encourage volunteerism. She proposes "a charitable volunteerism deduction (or tax credit) [that] would be available to people who volunteer at least thirty-five hours in a taxable year, engaged in meeting the needs of marginalized individuals and/or communities." Further, she recommends that the tax credit be available both to taxpayers who itemize and do not itemize their deductions.).

Pitt Tax Review | ISSN 1932-1821 (print) 1932-1996 (online)

DOI 10.5195/taxreview.2019.98 | http://taxreview.law.pitt.edu 
revise the Code to include a refundable tax credit, ${ }^{44}$ perhaps inspired by elements of the Earned Income Tax Credit. ${ }^{45}$

Since Congress has historically deployed tax credits to promote policy goals, this tax credit approach employs familiar social engineering tools. ${ }^{46}$ Further, a refundable tax credit provides a tailored and tested alternative to the universal basic income theory, which some critics argue can discourage the pursuit and performance of meaningful work. ${ }^{47}$ Although some may criticize this refundable federal tax credit proposal for (1) being too costly in terms of lost government revenues, (2) transforming "charitable work into waged labor," (3) constituting "essentially publicly funded employment," 48 or (4) creating complicated recordkeeping and reporting burdens, ${ }^{49}$ the following question remains: If a refundable tax credit does not represent a viable approach, what then is a reasonable and responsible alternative that provides human caregivers with the economic and social recognition they

${ }^{44}$ Lily L. Batchelder et al., Efficiency and Tax Incentives: The Case for Refundable Tax Credits, 59 STAN. L. REV. 23, 24 (2006) (arguing that "the government should provide tax incentives for socially valued activities: the default for all such tax incentives should be a uniform refundable tax credit"). Professor Batchelder and her coauthors describe the four elements of a refundable tax credit as follows:

It is a tax credit that is: (1) located in the federal income tax code, (2) administered in whole or in part through the tax system, (3) intended to induce certain behavior, and (4) "refundable," meaning that it is paid in cash when a tax unit has no federal income tax liability to offset (although frequently the claimant will have positive tax liability when other federal, state, and local taxes are taken into account). The refundable credits that we are interested in therefore stand in contrast to negative income taxes because they are intended to stimulate certain behavior.

Id. at 33 .

${ }^{45}$ See I.R.C. $\S 32$.

${ }^{46}$ See Michael B. Adamson, Note, Earned Income Tax Credit: Path Dependence and the Blessing of Undertheorization, 65 DUKE L.J. 1439, 1443-44 (2016) ("The EITC has grown from its humble beginnings to become the country's 'most significant federally administered antipoverty program."'); Batchelder et al., supra note 44, at 24.

${ }^{47}$ LEE, supra note 37 , at 220 (articulating a more ambitious public policy approach for a "social investment stipend" that would provide a "decent government salary" to human workers who "invest their time and energy in those activities that promote a kind, compassionate, and creative society."). Lee explains that the stipend would apply to "care work, community service, and education." Id.; see Mazur, supra note 33, at 326 (asserting that universal basic income "may dis-incentivize the desire to work" and "does not replace the physical and emotional benefits that working provides to individuals").

${ }^{48}$ See Staudt, supra note 43, at 988.

${ }^{49}$ Because new technologies will eventually streamline the required recordkeeping and reporting functions, such logistical concerns represent temporary impediments to the implementation of otherwise important public policy objectives.

Pitt Tax Review | ISSN 1932-1821 (print) 1932-1996 (online)

DOI 10.5195/taxreview.2019.98 | http://taxreview.law.pitt.edu 
deserve in an era where technologies routinely displace humans from the paid workplace?

\section{CONCLUSIONS}

In a future where $\mathrm{AI}$ and robotic technologies increasingly perform work and "market" functions, contemporary public and tax policies should expressly value human-performed "nonmarket" activities that technology cannot usurp. Further, the growing demand for "nonmarket" nurture and support services for retiring baby-boomers (with anticipated long life expectancies) will require thoughtful and coordinated government and community action. In view of the foregoing, congressional policymakers should study and then introduce forward-looking legislation that provides humans with opportunities to perform meaningful work.

A refundable tax credit is one solution. This approach provides an effective mechanism to compensate individuals of all sexes and genders who are called to serve their families and communities. Since the ability to love, care, and connect distinguishes humans from machines, it is now time for a fundamental rethink of our nation's priorities and values. 
